\title{
CAN INTERNATIONAL CAPITAL STANDARDS STRENGTHEN BANKS IN EMERGING MARKETS?
}

\author{
Liliana Rojas-Suarez \\ Visiting Fellow, \\ Institute for International Economics
}

This paper has benefited from the effective research assistance of Josh Catlin and Maria Unterrainer. 


\section{INTRODUCTION}

Who should determine banks' capital standards: authorities or markets? What is the right definition of core capital: equity only or equity plus subordinated debt? Can the assessment of banks' individual credit risks by external rating agencies be of equal or better quality than the assessments derived from banks' own internal rating systems? These are some of the key financial regulatory issues currently being discussed by analysts in industrial countries, especially in the context of the proposed modification to the Basel Capital Adequacy Accord: Basel II is expected to replace the original 1988 Accord.

With a few exceptions, these issues are certainly not at the center of the debate in emerging market financial circles. There, the financial issues at hand depend on the country's level of development. For the least developed countries, reform agendas are just advancing in the implementation of accounting standards, disclosure, and other principles of bank supervision; Basel II is certainly not in the medium-term future. If anything, implementation of the original Accord is the issue.

The more advanced emerging economies face a different dilemma. Albeit at very different paces, most of these countries embarked on a financial sector reform process in the early 1990s. One of the most important efforts by individual countries, also strongly supported by multilateral organizations, has been the adoption of the recommendations on capital adequacy requirements by the Basel Committee on Banking Supervision. However, in spite of significant advances in implementation, banking crises have abounded in emerging markets during the 1990s and early 2000s. Not surprisingly, some disillusion with a "traditional" reform agenda has emerged. A key debate, therefore, centers on assessing whether regulatory standards that work in industrial countries are appropriate for emerging markets. Among the most relevant issues are: (a) Can an early warning system of banking crisis particular to emerging markets be constructed? (b) How should capital adequacy ratios be designed in emerging markets? Should they diverge from the recommendations of Basel? And, (c) rather than focusing on "strengthening" banks, shouldn't emerging markets limit the role of banks, and instead, focus on the development of corporate bond markets?

This paper deals with the appropriateness for emerging markets of implementing capital requirements as recommended by the Basel Committee on Banking Supervision. The paper is part of a research agenda that I initiated in the late-1990s. ${ }^{1}$ In my previous research I concluded that such capital standards have had very little usefulness as a supervisory tool in emerging markets. 
For fundamental reasons that go beyond the improvements in regulatory procedures, and, instead center on the particular features of financial sectors in many emerging economies, the capitaltoasset ratio has not been a useful early warning indicator of banking problems.

While the limitations of capital requirements as a supervisory tool remain severe in most emerging markets, there are some countries where the increasing participation of foreign banks has helped to improve, at least to a certain extent, the usefulness of capital ratios. For these countries the appropriate choice of capital standards is key. In this paper, I advance the following questions: Can the adoption of the Basel recommendations weaken, rather than strengthen, the stability of banks in emerging markets where capital requirements are binding? Would the proposed modification of the Accord (Basel II) weaken even further the franchise value of emerging market banks? Unfortunately, the evidence seems to provide a positive answer to these questions. Therefore, I propose a set of alternative recommendations capable of strengthening banks in emerging markets.

The rest of the paper is organized as follows: relying on some of my previous work on the subject, section II first shows and then explains the reasons why capital requirements have not served their intended role as supervisory tools in many emerging markets. Section III demonstrates that adopting capital requirements as advanced by Basel, and especially by the proposed Basel II, may actually deteriorate the strength of banking systems in emerging markets. Section IV presents alternative proposals to strengthen banks according to the degree of financial development in emerging markets. Where capital requirements can be enforced, the paper advances suggestions for an improved capital standard. Section V concludes the paper.

\section{WHY CAPITAL REQUIREMENTS HAVE NOT CONSTRAINED RISK-TAKING BEHAVIOR OF BANKS IN MANY EMERGING MARKETS}

\section{Capital Requirements in Industrial Countries}

Financial authorities in industrial countries have at their disposal a number of tools to assess the quality of banks' balance sheets and off-balance sheet commitments. Among these tools, a set of financial ratios are used to convey the strength and volatility of a bank's earnings, the ability of the bank to remain liquid in the face of a temporary loss of access to short-term funding markets, its ability to withstand sharp changes in interest rates, and, above all, the quality of the bank's credit commitments, including letters of credit and derivatives as well as traditional loans. Undoubtedly, the summary statistic for bank risk, which includes a composite assessment of

1. See Rojas-Suarez and Weisbrod (1997), Rojas-Suarez (1999), and Rojas-Suarez (2001). 
credit and market risks, is the capitalto-risk-weighted-asset ratio. ${ }^{2}$ The capital ratio can take the function of a summary statistic for risk because, at least in theory, enforcement of each of the other supervisory ratios implies an adjustment in the value of assets and liabilities that ultimately affects the size of the bank's capital account. ${ }^{3}$

The ultimate intent of capital regulations is well described in a joint statement of the Shadow Financial Regulatory Committees of Europe, Japan, Latin America, and the United States (2001):

"Banks should maintain a level of capital that is sufficient to: (a) reduce the likelihood of bank insolvencies to a level consistent with a stable banking system; (b) immunize taxpayers from losses incurred by government-guaranteed bank claimants in the event of bank insolvencies; and (c) align the incentives of bank owners and managers with those of uninsured bank claimants with respect to the risks assumed by banks."

The attractiveness of the above statement is that it allows clarification on the issue of moral hazard, which has become a very controversial subject in recent times. The "consensus" for regulating banks is that these institutions operate within a public safety net: they have access to central bank funds in an emergency and they are often covered by publicly provided deposit insurance. These facilities allow banks to transfer some of the risk in their asset portfolios from shareholders to taxpayers without compensating them for that increased risk. Because safety nets create incentives for banks to take on more risk, banks must be supervised and regulated to restrain their ability to shift risk to the public. Forcing banks to have sufficient capital at risk is a way to achieve this objective; that is point (b) in the above quotation.

However, while the moral hazard problem derived from deposit insurance is a sufficient condition for justifying the need for regulation, it is not necessary. Even in the absence of deposit insurance, capital requirements are needed to minimize the eruption of a systemic banking crisis (point (a) in the statement above). While it is not only unavoidable but also desirable to have individual banking failures, there is a vast experience demonstrating that systemic banking crises are extremely damaging to the functioning of the overall economy, regardless of the decision whether or not to bail out the banking system. The moral hazard problem arises here because banks realize that, more often than not, the cost to society of not bailing out the banking system is larger than the cost of the bailout. Requiring sufficient capital not only helps to minimize the

2. A full discussion on how supervisory ratios are intended to work in industrial countries can be found in Rojas-Suarez and Weisbrod (1997).

3. For example, an increase in loan-loss reserves reduces the value of the net loan portfolio without changing the value of nonequity liabilities. As a result, the amount of bank capital decreases. 
occurrence of crisis but also, if a crisis erupts, minimizes the total social cost of crisis resolution. The lesson here is that capital requirements also need to be linked to the risk of systemic failures rather than solely to the risk of the individual bank's assets. The immediate question that comes to mind, of course, is why the Basel Committee recommendations on banks' capital adequacy set the overall minimum capitalto-risk-weighted-asset ratio at a fixed 8 percent. Clearly, the risk of a systemic banking crisis varies significantly across countries, especially when we draw a line between industrial and emerging countries. I will develop this issue further in the next sections.

Finally, point (c) in the quotation refers to the need of allowing market discipline to work to complement capital requirements. Noninsured bank claimants, such as those holding subordinated debt or uninsured deposits, can be a valuable source of bank stability if their actions lead bank owners and managers to augment bank capital. For example, if the risk perception of a bank's portfolio deteriorates, holders of subordinated debt can send a clear signal to bank owners and managers by selling their claims on the bank. The incentive for bank owners, therefore, is to increase their holding of capital to a level compatible with the increased risk in their asset portfolio. There are two important features of the role of market discipline. The first is that the level of capital required by the market need not be the same as the regulatory capital. The second is that market discipline is a nonregulatory approach to the moral hazard problems discussed above.

From the perspective of regulators and supervisors in industrial countries, the implementation of capital requirements has been a helpful tool in their efforts of constraining bank risk. The central guide for regulating bank capital requirements has been provided by the Basel Capital Accord (the so-called "Accord") published in 1988 by the Basel Committee on Banking Supervision. Since then, developments in financial technology have made evident severe limitations of the initial Accord in the appropriate assessment of bank risk. Two central criticisms of the Accord have been: (a) its rigid structure in the computation of banks' individual risks, and (b) its inadequate attention to the powerful role of market discipline in constraining excessive risk-taking activities by banks. As a result, the Basel Committee has issued a new proposal to modify the current Accord. The main elements of the proposed BaselII are presented in the appendix.

\section{Have Capital Requirements "Worked" in Emerging Markets?}

In spite of the problems leading to the proposal of Basel II, the consensus in industrial countries is that capital requirements (determined by the authorities or the markets) are an efficient mechanism to ensure bank soundness; indeed, the debate in industrial countries is not whether 
"capital" is the appropriate supervisory tool. Instead, the discussion centers on issues such as: (a) who should determine the right amount of bank capital: the authorities or the markets? (b) what instruments should count as core capital: only equity or subordinated debt as well?

Encouraged by the perceived success of capital requirements as a supervisory tool in industrial countries, emerging markets have been advised to adopt similar rules for capital adequacy. Indeed, since the late 1980s many emerging markets have directed their financial reform efforts toward implementing the recommendations of the Accord. ${ }^{4}$ However, albeit with quite diverse outcomes, the recent experience of banking problems in emerging markets indicates that capital requirements have not usually performed their expected role as an effective supervisory tool in many emerging markets.

My previous work on this issue helps to substantiate the statement above. As discussed above, the accumulation of capital in banks' balance sheets should act as a "buffer" to deal with unexpected adverse shocks to banks, in order to minimize the likelihood of severe financial disturbances. Consider the following questions: Has the accumulation of net equity capital (defined as equity net of surplus and retained and current earnings) in banking systems of emerging markets contributed to preventing the eruption of crises? At the micro level, have the capital adequacy requirements acted as an effective early-warning mechanism signaling problems in individual banking institutions? In what follows I address these two highly interrelated questions.

Chart 1 shows growth rates of banking systems' net equity during the year previous to the eruption of a major banking crisis. If equity capital is at all a good indicator of banking soundness, banks in countries about to fall into a major crisis should be facing difficulties in raising capital. This has indeed been the case in banking crisis in industrial countries. As shown in chart 1, during the year before the eruption of banking crises in Sweden, Norway, and Japan, net real equity growth became negative. The chart also illustrates a noncrisis episode in the United States to show that in "normal times" net real equity grows at moderate rates. ${ }^{5}$ In contrast, at the eve of disastrous crisis episodes in emerging markets, real net equity growth was not only positive but also reached very high levels. Cases in point are Thailand, Mexico, and Ecuador where, judging from the rapid accumulation of equity capital, there did not seem to be signals of major banking turbulences.

4. Of course, implementation of capital standards have been one of many components of financial sector reforms, including, among others, improvements in standards of asset evaluation, reform of supervisory procedures and training of supervisors, reform of deposit insurance schemes, etc.

5. Net real equity growth in the US banking system was 1 percent in 1993. 
Chart 1:

Real Net Equity Growth in Selected Banking Systems at the Eve of a Crisis*

(in percent)

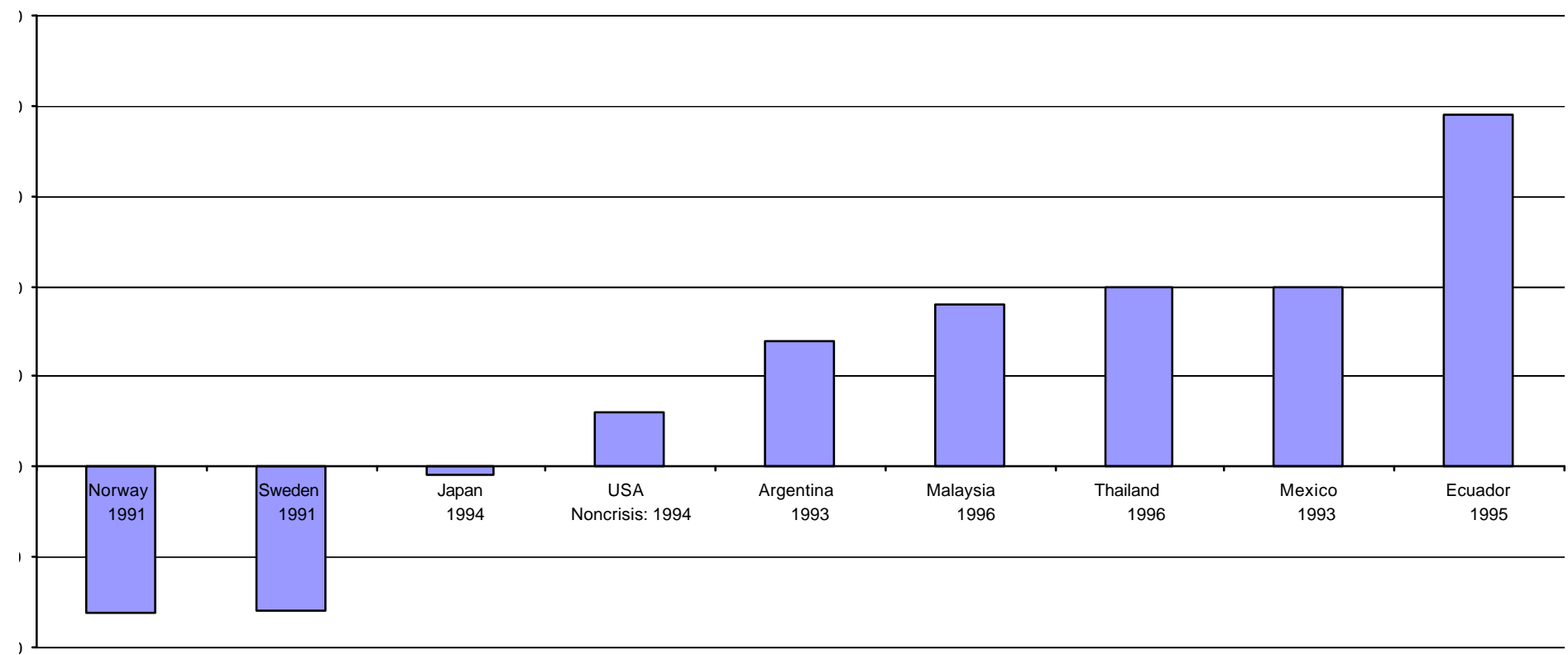

*Except the United States data, which is presented as a benchmark.

Sources: Rojas-Suarez and Weisbrod (1997), Rojas-Suarez (2001), various Central Bank statistics and IFS data.

It could be argued that the high rates of growth of real capital in emerging markets resulted from an alternative explanation: rapid growth rates in real terms could be attributed to the fact that bank capital in these countries started from a very low base relative to large industrial countries and, therefore, that the data indicate a stock adjustment problem rather than the low quality of the market for bank stock. It is to deal with this issue that I included two small industrialized economies in the chart: Norway and Sweden. As I discussed above, on the eve of their banking crisis (1991) the rate of growth of net equity behaved as expected for industrial countries: in the presence of problems in the banking system, net equity growth became negative in real terms. The issues related to the rapid growth rate of bank capital seem to be related to the country's degree of development rather than its size.

How can we explain the seemingly paradoxical result that rapid accumulation of equity in emerging markets' banking systems has not been able to prevent crisis? I answer this question in the next sub-section. First, I want to further demonstrate that capital ratios have been meaningless in signaling banking problems by briefly summarizing the results obtained in Rojas-Suarez (2001). 
Consider a representative set of "traditional indicators" used by supervisors to assess the strength of individual banks. While the list is long, there are five widely used key indicators: capitalization ratios, the ratio of net profit to total income, the ratio of operating costs to total assets and the ratio of liquid assets to total deposits, and the ratio of nonperforming loans to loans. To determine the appropriateness of these indicators as providing early warning signals of banking problems, I use the "signal approach" popularized by Kaminsky and Reinhart (1999). The main idea of the approach is that an indicator that exceeds a prespecified threshold provides a "signal" that should alert supervisors, analysts, and market participants to the weakening of a bank's performance. To assess the quality of the signal, therefore, it is necessary to determine the thresholds explicitly. An extensive definition of the thresholds is contained in Rojas-Suarez (2001). For the purpose of this paper it is sufficient to define the threshold used for the capitalization ratio: the capitalization ratio of a given bank is said to provide a "signal" if the ratio experienced a decline of more than 10 percent that persisted for at least two consecutive quarters. In countries where information for risk-weighted-capital-to-asset ratios was available, I included an additional threshold: a capitalization ratio that remained less than 8 percent for at least two consecutive quarters.

An indicator is considered "good" when it emits a signal that is followed (within 12 months) by problems in the bank in question, or when no signal is emitted and no problems follow. Likewise, an indicator is considered "bad" when its emission of a signal is not followed by bank problems, or when no signal is issued and problems follow.

Table 1 summarizes some of the results of this exercise for six emerging markets. In each country, the period analyzed is the one immediately previous to a major banking crisis. Individual banks in each country were classified as "crisis" or "noncrisis" banks. To decide on the classification of every bank, I used two criteria: (a) the bank was intervened, closed, or given significant injections of public capital; or (b) the ratio of nonperforming loans to total loans reached levels well beyond those achieved in "tranquil" (noncrisis) periods. ${ }^{6}$ The table assesses the "traditional indicators" mentioned above plus, when available, the ratio of equity prices. The reason for including this additional indicator is, of course, to evaluate whether the equity market provides a signal of bank difficulties. ${ }^{7}$ At the bottom of the table, I have included an additional

6. For the latter criteria, a bank is said to be "in crisis" if its ratio of nonperforming loans to total loans is greater than the average for the system as a whole during a tranquil period plus two standard deviations. 7. The ratio of nonperforming loans to total loans is not included as an early warning indicator because, as I explained above, this ratio was used as a criteria to classify banks between "crisis banks" and "noncrisis banks" 
indicator as a "memo item": interest rate on deposits. I will postpone discussion of this nontraditional indicator to section IV.

There are two columns for every country in table 1. The first column, entitled "Accuracy in Predicting Bank Problems", shows the ratio of episodes of bank problems accurately signaled in advance by the indicator, as a percentage of all such episodes. For example, a ratio of 10 next to an indicator tells us that the indicator correctly identified only 10 percent of all "crisis banks" episodes. The second column, entitled "Ratio of Good to Bad Signals", is the number of episodes for which an indicator provided "good" signals divided by the number for which the indicator provided "bad" signals. A ratio greater than one implies that the indicator issued a "good" signal more than 50 percent of the times.

The results from table 1 speak for themselves. With respect to their accuracy in predicting bank difficulties, while the traditional indicators did not perform well (with the possible exception of the ratio of net profits to income), the capitalization ratio was the worst performer! In the Mexican case, a country that claimed to have adopted the capital standards recommendations of Basel just before the eruption of the 1994 banking crisis, the risk-weightedcapital-to-asset ratio predicted accurately only 7 percent of crisis-banks episodes. Indeed, according to the data provided by the Supervisory Authority, most banks in Mexico were in full compliance with capital requirements and held a ratio well above 8 percent! In other countries, like Korea, the capitalization ratio was completely meaningless: it always provided a signal of bank distress and, therefore, the authorities had no tool to distinguish between solvent banks and banks in problems. ${ }^{8}$

The same results are obtained by analyzing the ratio of good to bad signals. With the exception of Venezuela, the "quality" of the capitalization ratio as an early warning signal was extremely low. Once again, Mexico, with a ratio of 0.35 , is noteworthy.

\section{What Explains the Poor Performance of Capital Requirements as a Supervisory Tool in Emerging Markets?}

There are a number of reasons for the disappointing performance of capital requirements as an effective supervisory tool in emerging markets. My main argument is that for capital

8. Consistent with this result, when available, the indicator column "change in equity prices" also performed very poorly. 
Table 1. Assessing the quality of traditional indicators of banking problems in Mexico (1993-94), Venezuela (1993-94), Colombia (1981-88), Thailand, Korea, and Malaysia (1996-97)

\begin{tabular}{|c|c|c|c|c|c|c|c|c|c|c|c|c|}
\hline Countries & \multicolumn{2}{|l|}{ Mexico } & \multicolumn{2}{|l|}{ Venezuela } & \multicolumn{2}{|l|}{ Colombia } & \multicolumn{2}{|l|}{ Thailand } & \multicolumn{2}{|l|}{ Korea } & \multicolumn{2}{|l|}{ Malaysia } \\
\hline $\begin{array}{l}\text { Traditional } \\
\text { Indicators: }\end{array}$ & $\begin{array}{l}\text { Accuracy in } \\
\text { predicting } \\
\text { bank } \\
\text { problems } \\
(\%)\end{array}$ & $\begin{array}{l}\text { Ratio of } \\
\text { good to } \\
\text { bad } \\
\text { signals }\end{array}$ & $\begin{array}{l}\text { Accuracy in } \\
\text { predicting } \\
\text { bank } \\
\text { problems }(\%)\end{array}$ & $\begin{array}{l}\text { Ratio of } \\
\text { good to } \\
\text { bad } \\
\text { signals }\end{array}$ & $\begin{array}{l}\text { Accuracy in } \\
\text { predicting } \\
\text { bank problems } \\
(\%)\end{array}$ & $\begin{array}{l}\text { Ratio } \\
\text { of } \\
\text { good } \\
\text { to bad } \\
\text { signals }\end{array}$ & $\begin{array}{l}\text { Accuracy in } \\
\text { predicting } \\
\text { bank } \\
\text { problems } \\
(\%)\end{array}$ & $\begin{array}{l}\text { Ratio } \\
\text { of } \\
\text { good } \\
\text { to bad } \\
\text { signals }\end{array}$ & $\begin{array}{l}\text { Accuracy in } \\
\text { predicting } \\
\text { bank } \\
\text { problems }(\%)\end{array}$ & $\begin{array}{l}\text { Ratio of } \\
\text { good to } \\
\text { bad } \\
\text { signals }\end{array}$ & $\begin{array}{l}\text { Accuracy } \\
\text { in } \\
\text { predicting } \\
\text { bank } \\
\text { problems } \\
(\%)\end{array}$ & $\begin{array}{l}\text { Ratio o } \\
\text { good tc } \\
\text { bad } \\
\text { signals }\end{array}$ \\
\hline Capitalization & 7 & 0.35 & 31 & 1.13 & 14 & 0.52 & 30 & 0.66 & $\begin{array}{l}\text { Meaningless } \\
(100)\end{array}$ & $\begin{array}{l}\text { Always } \\
\text { gave a } \\
\text { signal }\end{array}$ & 37 & 0.9 \\
\hline equity prices & 37 & 0.5 & n.a. & n.a. & 25 & 0.50 & n.a. & n.a. & n.a. & n.a. & n.a. & n.a. \\
\hline $\begin{array}{l}\text { Net profits to } \\
\text { income }\end{array}$ & 60 & 0.88 & 13 & 1.56 & 43 & 3.55 & 60 & 0.75 & 60 & 1.7 & 50 & 0.9 \\
\hline $\begin{array}{l}\text { Operating costs } \\
\text { to assets }\end{array}$ & 40 & 0.63 & 13 & 1.13 & 29 & 0.79 & 20 & 1.0 & 20 & 0.78 & 25 & 0.75 \\
\hline Liquidity ratio & 7 & 0.36 & 13 & 1.00 & 29 & 1.00 & 50 & 0.60 & 56 & 1.8 & 60 & 0.5 \\
\hline deposits & 80 & 2.13 & 69 & 2.57 & 71 & 1.00 & 66 & 3.66 & 80 & 1.5 & 62 & 1.3 \\
\hline
\end{tabular}

n.a.: not available Source: Rojas-Suárez (2001). 
requirements to work as effective indicators of bank strength, two sets of conditions need to be met. The first relates to the quality of data and the supervisory framework and the second to the existence and efficiency of markets. The first set of conditions is well known. It is widely recognized that in spite of progress, several countries in the region are still far from complying with the accounting and regulatory frameworks needed to make the capital adequacy standards work. Inappropriate accounting standards and reporting systems, improper classification of nonperforming loans and underprovision of reserves against credit losses stand out as the best examples of these inadequacies. In addition, a deficient legal framework, unable to enforce supervisory actions when a bank's performance is deemed faulty, seriously undermines the efficiency of bank ratios.

At a more fundamental level, however, the second set of conditions relates to a feature particular to emerging economies, namely the lack of deep and liquid capital markets. Even when accounting, reporting, and legal frameworks are adequate, capitalization ratios will be less effective if liquid markets for bank share, subordinated debt, and other bank liabilities and assets are not available to validate the "real" value of bank capital as distinct from its accounting value. For example, changes in the market value of bank capital provide supervisors in industrial countries information regarding the quality of reported capital.

In contrast to industrial countries, asset ownership, both financial and real, is highly concentrated in emerging markets. Because wealth is highly concentrated, the potential market for equity capital is small and hence concentrated and uncompetitive. In such an environment, the intent of the capital standard-to increase the proportion of uninsured funding (equity and subordinated debt) to insured funding (deposits) in order to reduce bank stockholders' incentive to take risks at the expense of existing public safety nets—can be easily subverted. ${ }^{9}$ This fact arises because supervisors have difficulty determining whether shareholders' wealth is really at risk when they supply equity capital to a bank, since shareholders can finance the ir stake with a loan from a related party, which may even be a nonfinancial corporation, and hence outside the regulators' purview. Thus, concentration of wealth provides incentives for bank owners to supply

9. This point has been advanced by Rojas-Suarez and Weisbrod (1997) and Rojas-Suarez (2001). 
low-quality bank capital and, therefore, undertake higher risks than in industrial countries.

This suggests that it can be relatively easy for bank owners in emerging markets to raise large amounts of low-quality equity capital relative to the bank's capital base in a short time. Indeed, I believe this feature explains the results shown in chart 1 and table 1: the rapid growth of net "accounting" equity displayed at the eve of banking crises in several emerging markets reflects the "low quality" of capital in these economies. Lacking a market that assesses the quality of bank capital, capitalization ratios cannot reveal the "true" riskiness of bank activities and, therefore, cannot serve as an effective component of an "early warning" system.

Clearly, the severity of this problem varies widely across emerging markets. For most of the countries, the constraints limiting the usefulness of capital requirements are extremely binding, begging the question: Is there an alternative to the use of capitalization ratios for assessing the strengths of banks? I will deal with these questions in section IV.

In some other countries, however, a continuous increase in the participation of foreign banks from industrial countries is de facto reducing the degree of related lending activities among financial institutions and between financial institutions and the real sector. Furthermore, in this (still small) group of countries, the accounting, regulatory, and supervisory frameworks have improved drastically. Although there is still no emerging economy with sufficiently deep and liquid capital markets, ${ }^{10}$ the participation of foreign banks can provide an outside source of capital for the pursuit of new wealth. The competition induced by the entry of new providers of wealth can indeed contribute to improve the usefulness of capitalization ratios. For this group of countries, the relevant question is whether adopting the internationally accepted capital standards recommended by the Basel Committee is appropriate (both, the current and the newly proposed Accords). The next section focuses entirely on this issue.

10. Although Chile may be the country, among emerging markets, with the deepest financial sector, it is still far away from the levels of development reached by industrial countries. 


\section{THE DISTORTIONS CREATED BY ADOPTING INTERNATIONAL CAPITAL STANDARDS: CAN THEY ACTUALLY WEAKEN BANKING SYSTEMS IN EMERGING MARKETS?}

This section deals with a central concern for supervisors in emerging markets: Are the capital standards used in industrial countries appropriate for emerging economies? In the previous section, I discussed the conditions needed for "any" capital standards to become an effective supervisory tool. In this section, I pose a different issue. Suppose that through a combination of improved regulatory and supervisory frameworks as well as the establishment of foreign banks, the restrictions imposed by the lack of domestic capital markets are ameliorated. This is indeed the case in some emerging market economies. In this situation what is the "right" capital standard to adopt? To answer this question, one needs to remember that a capital standard is as good as its classification of assets according to risk. ${ }^{11}$ In the ideal situation, the classification of assets according to risk "mimics" the assessment of risk by the markets. Conversely, if an asset perceived as risky by the market is classified within a "low risk" category in the standard, the resulting capital does not meet its function of providing a cushion to deal with unanticipated adverse shocks.

The question is: how well do capital requirements derived from Basel I or the proposed Basel II reflect the risks taken by banks in emerging markets? From the analysis in this section, I conclude not well at all. My main argument is that the enforcement of Basel in emerging markets (where possible) has distorted the allocation of credit. To the extent that this has resulted from an inappropriate assessment of risk, one can argue that the capital standards have actually increased the risk characteristics of banks' portfolios. I will discuss two features of the standards that, when applied to emerging markets, have weakened rather than strengthened banks' balance sheets. The first is the treatment of government claims held by banks and the second is the treatment of interbank lending. ${ }^{12}$

11. Discontent with the current classification of risks in the current Accord is precisely the reason behind proposals for modification.

12. These features of the Accord relate to the "relative" assessment of risk rather than the "absolute" assessment of risk. Given the features of emerging markets discussed above, it is not difficult to understand why several emerging markets have imposed a risk-weighted-capital-to asset ratio well above the minimum 8 percent recommended by the Basel Committee (in both the currently and the recently proposed Accord). 


\section{Crowding Out the Private Sector: Distorting the Intention of the Accord}

A distortion related not to the recommendations in the current and proposed Accords but to the implementation of these recommendations in emerging markets, is the treatment of bank credit to the government. Under the current Accord, loans to the public sector carry a 0 percent risk weight if the country belongs to the OECD and 100 percent if the loan is to a non-OECD government. The idea, of course, is that government claims from OECD countries can be considered "safe assets". However, when applying the Basel recommendations to their domestic economies, most non-OECD countries attach a 0 percent risk weight to their own government paper. That is, banks in emerging markets treat paper issued by their governments as a "safe asset", an assumption far from reality if one takes into account the large number of episodes of "government debt" crises in emerging markets, including the recent ones in Russia and Ecuador. The problem with this practice is that by economizing on capital requirements, banks have a strong incentive to concentrate a significant portion of their asset holdings in government paper. This incentive not only gives a false impression of "bank safety," but even more importantly, also contributes to weaken the "franchise value of banks," which is rooted in their capacity to assess credit risk.

Chart 2 shows the severity of this problem by comparing the share of government paper in banks' balance sheet during the 1980s and the 1990s for a number of emerging economies. The chart shows that such a share has increased during the 1990s for the majority of countries in the sample (most of the countries are depicted to the right of the 45 degree line). For many emerging markets, this result has a sad irony: a significant component of the efforts of financial sector reform undertaken in the early 1990s aimed at decreasing the share of banks' claims on government! It is important to note, of course, that the results in chart 2 should not be entirely attributed to an inappropriate implementation of regulatory reform. In a number of countries, banking crises were

At the "system" level, high economic and financial volatility exacerbates the conflicts in incentives between depositors and banks' stockholders. Not surprisingly, banking crises in emerging markets have been characterized by much larger losses of deposits than in banking crises in industrialized countries. Following the "principles" for adequate bank capitalization discussed in section I, higher volatility calls for a larger capital cushion, and therefore, for risk-weighted capital-to-asset ratios significantly larger than 8 percent. This issue has been stressed by Gavin and Hausmann (1996). 
resolved by replacing bad loans with government paper (Mexico and the post 1997-East Asian crisis countries are notorious for this). Given the lack of access of emerging markets to international capital markets during crisis periods, it is very difficult to conceive alternative procedures for banking crisis resolution. To take this into account, I eliminated banking crisis periods from the sample, including five years after the crisis. The basic result did not change: most banking systems in emerging markets held as much or more government paper in the 1990s than in the 1980s. ${ }^{13}$

\section{Chart 2:}

\section{Claims on central and noncentral government as a percentage of total assets of deposit money banks 1980s against 1990s}

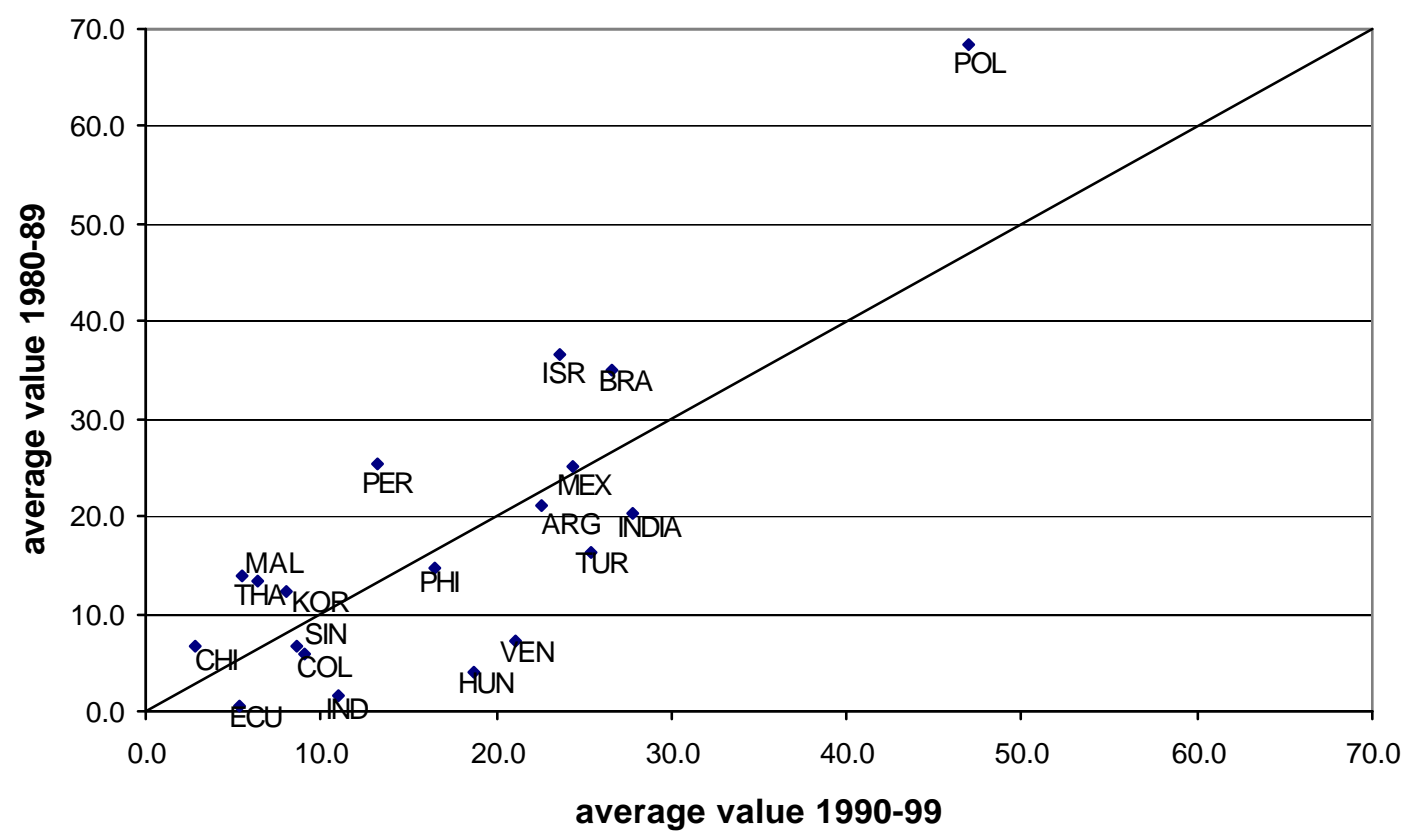

As chart 2 shows, the ratio of claims on government as a percentage of deposits not only has increased for most countries but is also very high. Large countries such as Argentina, Brazil, India, Mexico, and Poland display ratios above 30 percent. Indeed,

13. The case of Argentina is particularly telling. During the early 1990s, following the implementation of the currency board, banks decreased their relative holding of government paper. After the banking crisis of 1995, there was an increase in holdings of government paper that one can ass ociate with the restructuring efforts of the financial sector, including improving the liquidity of the banks. However, way after the crisis was completely resolved, banks continued to increase their claims on government. By the end of 2000 the share of banks claims on central and noncentral government as a percentage of total assets reached 25 percent, a ratio close to the 27 percent observed in 1991 at the beginning of the currency board. 
among the sample of countries, Chile can be singled out as a country that succeeded in reducing this ratio to low levels (1.7 percent by the year 2000).

While a thorough understanding of banks' decisions to hold public versus private assets require the specification of a complete model, it is fair to argue that the regulatory treatment of government paper has played an important role in banks' decisions. This regulatory incentive has important consequences during recessions as banks tend to magnify the downward trend in economic activity by shifting their portfolio further away from credit to the private sector and towards government paper. While the procyclical effects of provisioning requirements are well known (see the discussion below), I would add that such a problem is exacerbated by the regulatory bias toward government paper.

Chart 3 illustrates this problem. Since the eruption of the East Asian crisis in 1997, a number of emerging countries have experienced a sharp downturn in economic activity, including, during certain periods, negative growth. Prominent in the sample of countries are Argentina and Turkey. In these two countries, during recessionary periods, the share of banks' claims on government in total assets has increased continuously. Notice that this pattern was present in Turkey before the government recapitalization of banks that followed the eruption of a banking crisis in early 2001. The case of Argentina is even more straightforward as there has been no injection of public funds into the banking system during the period considered: banks in Argentina simply found it more profitable to decrease their share of assets to the private sector. 


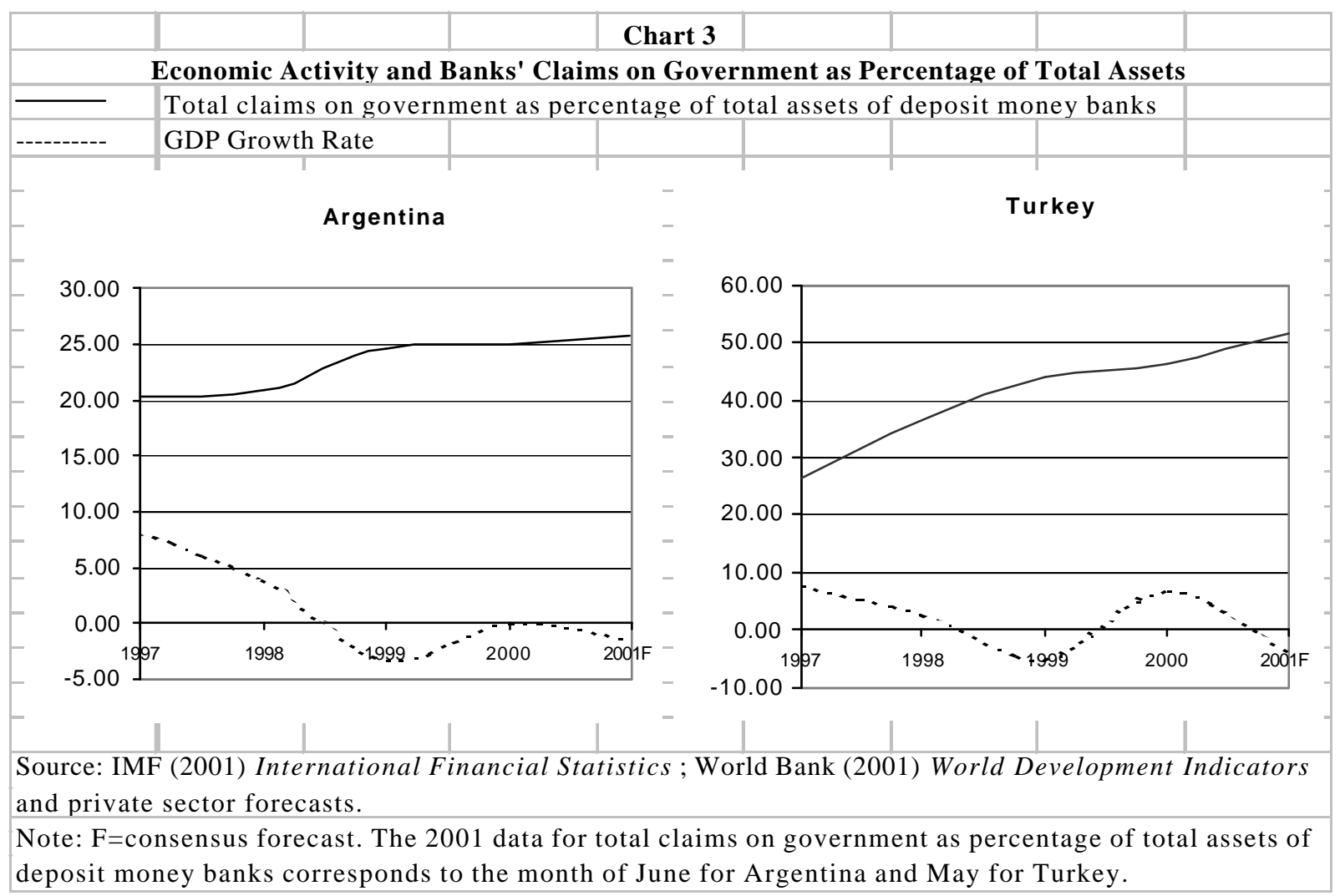

To further elaborate my point that this regulatory distortion weakens the franchise value of banks, I examined the market assessment on the quality of government debt, as reflected by the international spreads on sovereign paper. As shown in chart 4 , the banks' relative holdings of government paper increased continuously during 2000-01 in both Argentina and Turkey in spite of a sharp deterioration in the market assessment of risk of these assets. ${ }^{14}$

From my perspective, the evidence above suggests that the regulatory treatment of banks' claims on government tends to reduce the soundness of banking systems. A counter case may be made by arguing that domestic government debt is "safer" than external debt. However, given the long history of government-induced domestic defaults, either in the form of straight confiscation of deposits or sharp devaluations and inflations that drastically reduced the real value of government paper held by residents, I find this argument simply unconvincing. Moreover, the persistence of high domestic real interest rates at times of deteriorated international perceptions of a country's creditworthiness 
(as reflected by high spreads on external debt) indicates that perceptions of increased "country risk" by foreign investors are quickly translated into increased perception of risk by domestic investors. 15

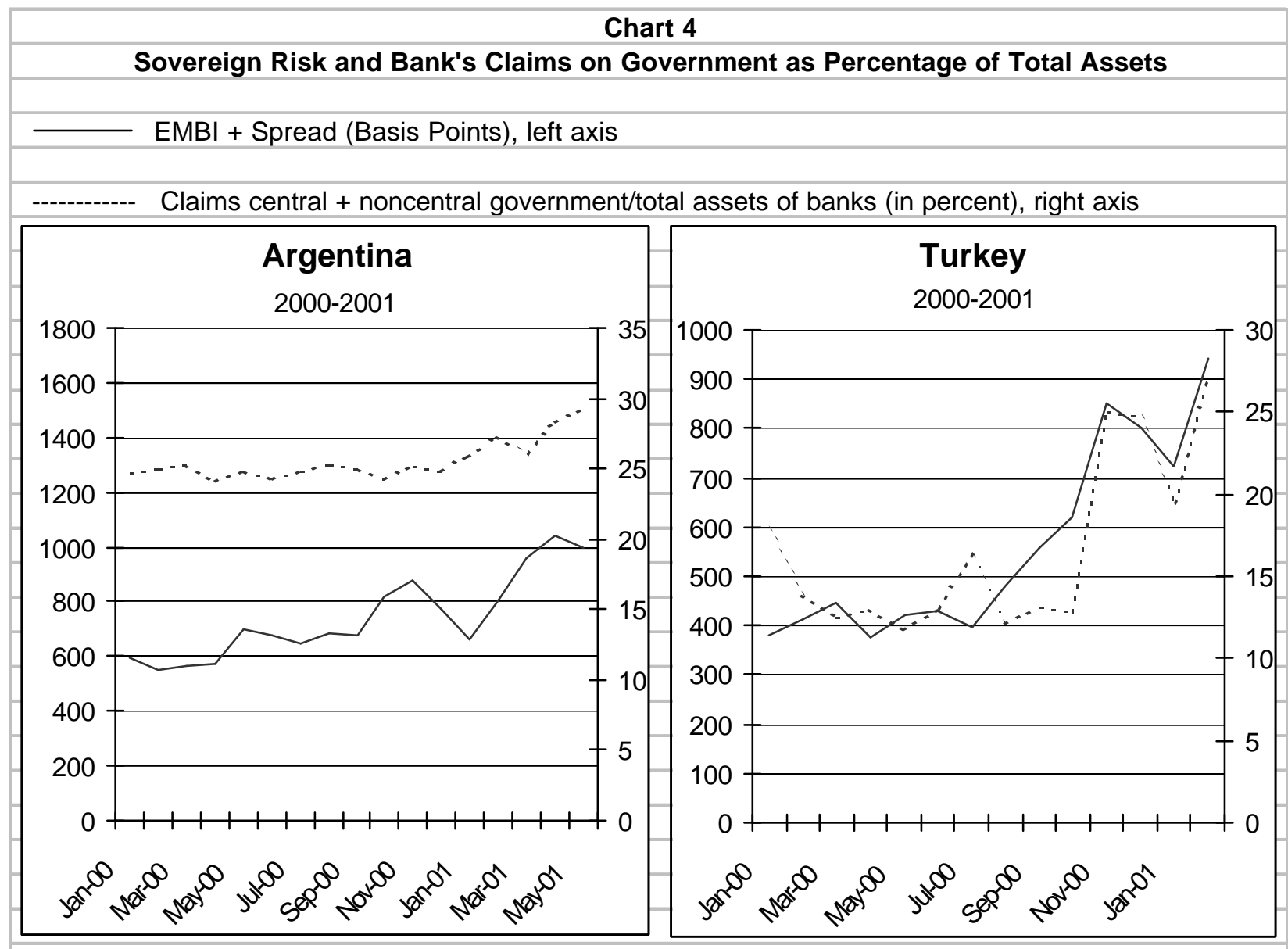

Sources: Bloomberg and IMF (2001) International Financial Statistics

Will the adoption of the new proposed Basel Accord correct this problem? I do not think so. The consensus among analysts is that the most likely outcome for emerging markets in the near future is that they will either keep the initial Accord in place or adopt the standardized approach of the newly proposed Accord. ${ }^{16}$ As explained in the appendix, under the standardized

14. This point is confirmed by the deterioration in sovereign paper ratings issued by credit rating agencies.

15. For a detailed presentation of this evidence, see Rojas-Suarez (2001a).

16. See, for example, Latin American Shadow Financial Regulatory Committee (2001). 
approach, risk weights are to be refined by referring to ratings provided by an external credit assessment institution. That is, ratings to both sovereign and corporate credits will be translated into risk-weight categories according to a predetermined conversion table. While at first sight this gives the impression that banks' risk of holding government paper will be determined by market forces, there is an "opt-out" clause to be applied at the discretion of individual countries. According to this clause, banks can attach zero- or low-risk weight to claims on the government where the bank is incorporated under the condition that the claim is denominated and funded in the currency of the sovereign. This clause opens a number of issues: should "currency" be interpreted only as the currency "issued" by the sovereign or can it also include the "medium of exchange"? Or can it also include the accepted "store of value"? If only the strict definition of "currency issued" is applied, governments from dollarized countries such as Ecuador and Panama cannot make use of this rule (see Powell 2001 for more on this discussion). If the "medium of exchange" concept is used, these countries plus others partially dollarized, such as Argentina and Peru, can continue their current practices. My view is that there are a number of emerging market governments with a strong incentive to continue the current practice of attaching zero-risk rates to their liabilities independent of the currency of denomination.

\section{Rules on Interbank Lending: Shortening the Maturity of Domestic Loans}

It has been widely recognized that Basel's treatment of interbank lending to non-OECD countries exacerbates the volatility of capital flows to these countries (see, for example, Reisen 2001 and Griffith-Jones and Spratt 2001). The fundamental reason is that while bank lending to non-OECD banks with a maturity of over one year is subject to a risk weight of 100 percent, lending to these banks with a maturity of a year or less face a risk weight of only 20 percent. The natural result has been an increase in short-term cross-border lending toward banks in emerging markets. Under these circumstances, any adverse economic or political "news" from these countries has resulted in an abrupt reduction of cross-border lending as short-term credit is either not renewed or it is renegotiated at very high interest rates. The proposed new Basel Accord increases this problem even further as the definition of short term has been reduced from "one year maximum" to "three months maximum". This means that in the case of international banks following the standardized approach, for a given rating category, a short-term loan is subject to fewer capital charges than a long-term one.

From the perspective of supervisors in industrial countries, the proposed modification of the Accord aims at strengthening their banking systems. However, it is also apparent that these regulations complicate the policy objectives of emerging market governments to increase in the 
maturity structure of their foreign liability. The importance of this problem can be seen in table 2 . Cross-border claims of BIS reporting banks on a large number of emerging markets tend to be concentrated on short-term maturities. Indeed, in early 2001, claims with maturity of a year or less reached more than 50 percent of total cross-border claims on almost half of emerging markets.

Table 2

Consolidated Cross-border Claims of BIS Reporting Banks on Individual Countri

By Maturity

End - March 2001

Cross-border claims with a maturity of one year or less

\begin{tabular}{|c|c|c|c|}
\hline & $\begin{array}{l}\text { Total (millions } \\
\text { of US dollars) }\end{array}$ & $\begin{array}{l}\text { Millions of } \\
\text { US dollars }\end{array}$ & $\begin{array}{c}\text { Percent of total } \\
\text { claims }\end{array}$ \\
\hline Argentina & 65,956 & 36,916 & 55.97 \\
\hline Bolivia & 1,430 & 812 & 56.78 \\
\hline Brazil & 67,777 & 33,554 & 49.51 \\
\hline Chile & 22,340 & 9,485 & 42.46 \\
\hline Colombia & 11,729 & 4,319 & 36.82 \\
\hline Ecuador & 1,509 & 861 & 57.06 \\
\hline Mexico & 68,931 & 26,305 & 38.16 \\
\hline Peru & 13,035 & 8,546 & 65.56 \\
\hline Venezuela & 12,668 & 4,661 & 36.79 \\
\hline China & 56,029 & 18,048 & 32.21 \\
\hline China, Hong Kong & 111,610 & 66,948 & 59.98 \\
\hline Chinese Taipei & 15,795 & 10,085 & 63.85 \\
\hline India & 20,189 & 7,561 & 37.45 \\
\hline Indonesia & 39,123 & 20,538 & 52.50 \\
\hline Israel & 8,162 & 3,562 & 43.64 \\
\hline Malaysia & 21,105 & 7,494 & 35.51 \\
\hline Philippines & 17,325 & 6,730 & 38.85 \\
\hline Singapore & 104,587 & 69,598 & 66.55 \\
\hline South Korea & 57,354 & 31,559 & 55.02 \\
\hline South Africa & 18,744 & 11,321 & 60.40 \\
\hline Thailand & 24,802 & 10,075 & 40.62 \\
\hline Bulgaria & 1,319 & 386 & 29.26 \\
\hline Croatia & 7,004 & 2,123 & 30.31 \\
\hline Czech Republic & 12,171 & 6,703 & 55.07 \\
\hline Hungary & 16,115 & 4,946 & 30.69 \\
\hline Poland & 23,775 & 9,210 & 38.74 \\
\hline Russia & 37,390 & 10,011 & 26.77 \\
\hline Slovak Republic & 3,577 & 1,297 & 36.26 \\
\hline Turkey & 43,641 & 27,397 & 62.78 \\
\hline
\end{tabular}

Source: BIS Quaterly Review, September 2001. 
What is not sufficiently recognized in the literature, however, is the effect of this regulatory incentive on the maturity of loans extended by domestic banks to the local economies. In what follows, I argue that the maturity of domestic loans will also tend to decrease with adverse consequences on domestic output volatility.

As part of their efforts to strengthen their banking systems, a number of emerging countries have introduced regulation aimed at reducing the maturity mismatch between assets and liabilities. In this area, regulatory frameworks vary significantly across countries. Some like Chile and Peru are simple and straightforward, limiting the maturity mismatch between assets and liabilities as a percentage of the bank capital. ${ }^{17}$ In other countries, such as Argentina, regulation is more sophisticated in that it estimates capital requirements by taking into account the risk to the loan portfolio of banks derived from maturity mismatches. ${ }^{18}$

Consider now the combination of "international regulation" creating incentives for banks in OECD countries to provide short-term loans to banks in emerging countries and "domestic regulation" aiming at controlling the maturity mismatch between banks' assets and liabilities. The result is quite clear: as the proposed Basel II reduces the maturity of interbank loans to emerging markets, the maturity mismatch in local banks would tend to increase. This in turn triggers domestic regulation calling for more capital. To economize on capital, local banks have an incentive to shorten the marginal maturity of loans, thereby increasing the vulnerability of economic activity to sources (and price) of funding. Thus, as a result of changes in regulations aimed at strengthening banks in industrial countries, emerging markets get hit by a double whammy. First, by facing a shortening in the maturity of their foreign sources of funding, local banks become more vulnerable to adverse external shocks. Second, by facing a shortening in the maturity of their loans, domestic producers (banks' borrowers) also become more vulnerable to adverse shocks.

17. For example, in Chile, the difference between total liabilities with a marginal maturity of less than 30 days and total assets with a marginal maturity of less than 30 days cannot exceed basic capital of the bank. This requirement holds for assets and liabilities denominated in domestic and foreign currency, separately for each currency and for the addition of all currencies. In addition, the difference between total liabilities with a marginal maturity of less than 90 days and total assets with a marginal maturity of less than 90 days can not exceed two times basic capital. This latter requirement is applied for the sum of all currencies. 18. This is in addition to the calculation of capital charges based on "market risk," that is, the risk to the value of tradable assets derived from variations in interest rates and exchange rates. The novelty in Argentina's methodology is that it explicitly recognizes that maturity mismatches also introduce risk to the value of the "banking book" (mostly the loan portfolio) and compute capital charges to take that risk into account. 


\section{Additional Features of the Proposed Revised Capital Accord that Weaken the Franchise Value of Banks in Emerging Markets}

The two features of the Basel Accord discussed above are not the only ones that tend to increase the fragility of banks in emerging markets. I have emphasized those two because they are characteristics of the current Accord as well as the proposed modified Accord. In other words, the problems that I have underlined are present now and, ironically, tend to get worse as emerging markets improve their ability to enforce international capital standards.

But, as has been repeatedly stated in numerous debates about the benefits and problems of the proposed modifications to the current Accord, there are features particular to the Proposed Accord (Basel II) that may potentially have adverse effects on the franchise value of banks in emerging markets. ${ }^{19}$ Next, I summarize these potentially adverse effects. Because they have been discussed elsewhere, no extensive explanation is needed.

\section{a. Potentially Weakened Supervision}

A potential adverse effect to the strength of banks in emerging markets arises from the impact of the proposed Accord on the supervisory activities in both industrial and emerging economies.

Consider first the impact on supervision in industrial countries. While at this stage it is very difficult to predict whether banks in industrial countries will follow the standardized approach or the internal rating-based approach, most analysts anticipate that major international banks from the United States and Europe will obtain approval to use their own internal capital allocation processes (see appendix). A number of other international banks actively lending to emerging markets, however, may be required to use the standardized approach.

A major risk for emerging markets stemming from international banks switching from the current Accord practices to the internal rating-based approach is that the large discretion given to banks and regulators arising from the proposal contains an inherit incentive for risk arbitrage by banks, and regulatory forbearance by the authorities. ${ }^{20}$ As stated by the US Shadow Financial Regulatory Committee: "The number, complexity, and opaqueness of the new rules established

19. What is special about banks, namely "the franchise value of banks" is the unique power conferred by the banking charter to issue liabilities that are accepted as a means of payment. For a banking system to keep its franchise strong the quality of their assets backing up their liabilities also needs to be sound. Rules and regulations that lead to increased risk in the asset portfolio of banks without a corresponding increase in the value of capital, weaken the franchise value of banks. See Rojas-Suarez and Weisbrod (1995).

20. This issue is further discussed in Benink and Wihlborg (2001) and the US Shadow Financial Regulatory Committee (statement no. 169). 
under the Basel proposal would add to regulatory forbearance by making it harder to hold regulators accountable for their judgments of bank risk."21

The potential weakening in supervisory practices in industrial countries would have adverse consequences for banks in emerging markets. First, regulatory forbearance in industrial countries may exacerbate the volatility of capital flows to emerging markets-interbank lending in particular. When an underestimated risk from a credit to an emerging market materializes, international banks will quickly reverse the inflows to economize on capital requirements. While this phenomenon is already present under the current Accord, the discretion introduced by the new Accord could indeed exacerbate the sharp turns in capital flows to emerging markets.

Second, through "contagion" effects, regulatory forbearance in industrial countries can severely weaken asset portfolios of banks in emerging markets. One of the best examples of this kind of contagion was provided by the East Asian crisis. In Japan, in the midst of the recent banking crisis, authorities relaxed regulatory and supervisory requirements to give additional time to banks to resolve their difficulties. However, as demonstrated by numerous episodes in a large number of countries, regulatory forbearance has effects opposite those expected by the authorities: banks increased rather than reduced their risk-taking activities. In the Japanese case, this practice involved increasing loans to banks and companies in East Asian countries without the appropriate assessment of the quality of projects. Fueled with additional funds, banks in East Asia also had the incentive to expand financing without due evaluation on project qualifications. As is well known, the end result was a deepening of the banking crisis in Japan and the weakening of banks in emerging East Asian countries, which contributed to the ensuing banking crisis in the region.

Now, let us turn to the supervisory problems created by the proposed modified Accord if it were to be implemented in emerging markets. For starters, it is useful to remember that the issue of insufficient training and expertise of bank supervisors in emerging markets is a serious one. Currently, many countries face this problem. Were the proposed Accord to be implemented, the problem would be exacerbated. The complexities of the new Accord call for more sophisticated and well-prepared supervisors. This issue by itself may be a major hindrance to the implementation of the proposal in emerging markets.

But what if an emerging market decides to go ahead in implementing the new Accord? The provision in the proposed Accord allowing banks to follow the internal rating-based approach would not seem to be relevant for most domestic banks in emerging markets. While there are a few domestic banks in a position to compete internationally and are qualified as strong

21. Taken from US Shadow Financial Regulatory Committee, statement no. 169. 
by international standards, such is certainly not the case for most banks in these economies. Moreover, given the discussion in section II, it would not seem advisable for most countries to adopt this approach. In general, I would envisage that if an emerging market country chooses to follow the revised Accord at all, it would also choose to follow the modified standardized approach for its domestic banks (see appendix). ${ }^{22}$ In this circumstance, the added supervisory issues would be related to the operations of rating agencies. I deal with these issues below.

In contrast to local domestic banks, large foreign banks operating in emerging markets may be allowed to follow the internal rating approach. This may be the case if the parent companies of foreign banks from industrial countries are allowed by their supervisors to follow the more advanced approach. The issue here is whether supervisors in emerging markets would also permit foreign subsidiaries to follow the internal rating approach when operating in the local markets. On one hand, foreign banks could be qualified to follow the advanced approach. On the other hand, domestic supervisors in emerging markets might not be prepared to control the quality of foreign banks' internal systems. Notice, however, that the supervisory problems would not disappear even if emerging markets were to rely on the supervisory body of industrial countries to assess the strength of sophisticated foreign banks. As I discussed above, financial specialists from industrial countries have stressed the potential for regulatory forbearance if banks were allowed to follow the internal rating approach.

While it is clear that a multitude of new supervisory issues would emerge if the proposed Accord were to be implemented, emerging markets need to give consideration to the potential benefits of foreign supervision under the current Accord. This matter, analyzed in Gavin and Hausmann (1997), is becoming more and more relevant in emerging markets as the proportion of foreign banks increases. The question is whether allowing sophisticated foreign banks to operate in the region should also require relying on the supervisory body of industrial countries. This system could be achieved if emerging market countries follow the European Union method of "home" supervision, where license granted to a bank to operate in its home country automatically implies license to operate in any other country in the EU. This policy would, in turn, imply that foreign banks need to be established in emerging markets as branches rather than subsidiaries. This, however, is a move that few foreign banks are ready to undertake at this point in time.

22. Given the diversity of financial systems in emerging markets, however, exceptions are of course possible. In this regard, a couple of countries may decide to apply the "foundation method" of the internal rating-based approach to a few of their domestic banks. Then again, the discussion on section II calls for strong caution in granting permission to domestic banks to follow this method. 


\section{b. $\quad$ A Potential Weakening of Credit Risk Assessments: The Incentives of Credit Rating Agencies}

Turning back to what I think would be the most common approach applied to banks in emerging markets (if the revised Accord is adopted at all), namely, the revised standardized approach, the most important modification relates to credit risk (market risk measures remain the same as in the current Accord). The incorporation of more categories for risk classification of credits, where the risk weights are determined with reference to a credit rating agency, would have important implications for emerging markets. Three problems stand out. One, common to both industrial and emerging markets, relates to the incentives of credit rating agencies to "inflate" the ratings. The other two relate to particular and interrelated features of emerging markets: the tiny proportion of firms rated and the lack of a regulatory framework for rating agencies.

First, as analyzed in Kaufman and Litian (2000), the use of credit rating agencies for the purpose of determining required capital may result in "biased" ratings of borrowers. The fundamental reason is that credit rating agencies will be "hired" by companies needing to borrow from banks. With the exception of the large corporations (which may already be rated), corporations selecting the rating agency will face an incentive to choose the one that produces the highest rating. This problem known as "the race to the bottom" would imply credit risk assessments that do not correspond to the true credit risk profile of the borrower. By attempting to improve on credit assessments introducing external rating agencies, the proposed Accord may actually result in a more distorted computation of banks' individual risks. ${ }^{23}$

Second, under current conditions, if an emerging market economy were to follow the proposed standardized approach, most companies would be assigned a 100 percent risk weight (that is the category for "unrated" companies). Because of the very limited activity of rating agencies in emerging markets, the "race to the bottom" problem would be exacerbated as the discrepancy between the "demand" for and "supply" of rating would be very large. Moreover, "ratings" being a scarce resource, its price may be sufficiently high as to discourage the incorporation of small, highly creditworthy borrowers into the system. A major problem that authorities would face is that implementing the standardized approach in emerging markets would further enhance the credit bias toward large corporations and large borrowers in general. ${ }^{24}$

23. Notice that this problem does not arise in the case of ratings of instruments placed by corporations placed in the capital markets. The reason is that bonds and equity are traded continuously and, therefore, there is always a market price to confirm or challenge the "quality" of the rating. This is not the case for bank loans as they are not generally traded.

24. Such is the case because under the current Accord, all corporations are subject to a 100 percent risk weight, while under the modified Accord, rated firms can be classified in four risk categories ranging from 20 percent to 150 percent. If, for example, a rating classification similar to that used by $\mathrm{S} \& \mathrm{P}$ were 
Moreover, there is a curious distortion in the proposed weighting system (also noted by the US Shadow Financial Regulatory Committee): a company rated below B- carries a 150 percent risk weight. This means that banks would have an incentive to lend to an unrated company rather than to one with a rating below B-. The incentive for weak companies not to be rated is apparent!

Finally, there is the issue of the development of a regulatory framework for the activities of rating agencies. As mentioned above, the implementation of the Accord may create the incentive for the eruption of domestic rating agencies to fill the needs of banks and corporations that would want to be rated. The policy issue is whether a proliferation of new agencies should be allowed or whether rating might be another service worth importing from industrial countries.

\section{c. The Procyclical Nature of Capital Requirements}

The current Accord has been widely criticized by policymakers and analysts in emerging markets due to its "procyclical" nature. Regulatory procyclicality occurs because in the midst of an economic contraction when nonperforming loans tend to increase significantly, banks are required to increase provisions, which, in turn, may result in capital ratios below the minimum required. As raising capital is expensive for banks, especially in downturns, the cost and availability of bank funding increases, exacerbating the recession and further deepening the nonperforming loans problem.

It has also been argued that the proposed modified Accord enhances the procyclical features of capital requirements, although there are different views about whether this effect would be greater under the internatrating based approach or under the standardized approach. ${ }^{25}$ As an example, consider the situation where foreign banks lending to emerging markets are required to follow the standardized approach. There are two major reasons why volatility of capital flows to emerging markets would increase, potentially destabilizing local banks that largely intermediate these flows. The first is that rating agencies already have a track record of lowering ratings after significant problems in emerging markets emerge. Indeed, credit rating agencies are better at "risk confirmation" than "risk diagnosis." As shown in Reinhart (2001), the performance of rating agencies in anticipating emerging markets' crises has been poor. The second reason is that, de facto, sovereign ratings constitute a ceiling for ratings to the private

followed, banks could economize on capital requirements by lending to corporations rated with an "A" rating level (20 percent risk weight) or with a "high B" rating (50 percent risk weight).

25. For example, Reisen (2001) argues that the rise in risk weights required by the internal ratings-based approach would effectively eliminate most emerging market countries from access to international capital bank lending. Powell (2001) summarizes this debate. 
sector. ${ }^{26}$ If international banks have to increase their capital charges in accordance with changes in these ratings, capital outflows from emerging market countries facing difficulties may increase significantly for regulatory reasons. It could be argued that the reversal of inflows from international banks to emerging countries occurs now, without the role of rating agencies on capital adequacy requirements. However, it should also be clear that the additional regulatory constraint would imply the loss of a degree of freedom in the bilateral negotiations between international banks and emerging countries.

\section{FACING THE CONSTRAINTS: WHAT ARE THE APPROPRIATE CAPITAL STANDARDS FOR EMERGING MARKETS?}

As I have argued throughout this paper, the wide range of financial developments among emerging markets implies that a uniform framework for capital standards may not be appropriate for all countries. In a broad sense, emerging market economies can be divided into two groups. The first group includes those countries where the combination of : (a) a high concentration of financial and real wealth in domestic hands and, (b) the lack of adequate basic accounting and transparency standards, severely constrain the usefulness of any capital requirement as a supervisory tool. The second group is formed by those countries where, although domestic capital markets remain shallow, foreign banks have contributed to improve the usefulness of capital ratios by providing an outside source of capital for the pursuit of new wealth. In this second group of countries, the accounting, regulatory, and supervisory frameworks have improved drastically.

A lesson learned from the evolution of regulation in industrial countries is that regulators seeking to constrain the risky behavior of banks need to rely on a pool of investors who evaluate bank risk from a market perspective. ${ }^{27}$ This implies that market discipline is a necessary condition for successfully enforcing regulatory policies. The different degree of financial development among emerging markets does not invalidate this principle. What this means is that regulators from the least developed financial markets would have fewer markets to rely on. For example, in contrast to their counterparts in industrial countries, regulators in emerging markets can not rely on the signals provided by the capital markets-through fluctuations in the price of bank equity and subordinated debt—

26. On this issue, see Ferri, Liu, and Majnoni (2000).

27. After all, the purpose of "effective regulation" is to mimic the behavior of the market in the absence of the initial distortion (such as deposit insurance, externalities, etc.) that led to the imposition of regulation in the first place. 
Based on the principle that markets have to "validate" the work of regulators and supervisors, I develop the following set of recommendations for each of the two categories of emerging market economies.

\section{Policy Recommendations for Emerging Market Economies Where Capital Requirements Have Limited Usefulness}

In section II, I discussed the reasons why capital requirements in a number of countries may not be effective in controlling the risk-taking activities of banks. While the sustainable policy consists in removing the constraints to the effectiveness of capital standards, those policy reforms often take a significant amount of time. In the transition toward more comprehensive reform, it is essential to identify and develop indicators of banking problems that reveal the true riskiness of banks. The recommendations that follow assume, but do not specifically discuss, the obvious ones related to the improvements in the accounting, regulatory, and transparency framework where banks operate, as well as those reforms related to the improvements in the legal and judiciary system essential for the proper interrelationship between creditors and borrowers. These recommendations have been discussed extensively elsewhere.

\section{a. Identify Indicators that Provide Early Warning Signals of Bank Problems and Develop the Channels of Market Discipline}

As has been repeatedly stated above, market discipline is essential for increasing the effectiveness of supervision in emerging markets. As concentration of financial and nonfinancial wealth makes it difficult for supervisors to depend on capital standards to control bank risk, authorities must make do, at least in the short-run, with the limited markets that are available for pricing bank risks, namely, the liability markets. Because these markets can provide signals about the relative strength of banks, a high priority needs to be given to ensure that these markets work as effectively as possible.

In most emerging economies, deposit markets work. This is because the process of financial liberalization that most countries undertook during the 1990s largely involved the liberalization of interest rates on bank deposits and loans. Indeed, in spite of the distortions created by deposit insurance, interest rate on deposits can be included as part of a set of an effective early warning system of banking problems. To see this, turn back to table 1 . In section II, I showed that capital ratios had not performed well as an indicator of banking problems. Now, consider the memo item in the table, namely the interest rate on deposits. Among all the indicators presented in the table, interest rate on deposits was clearly the best performer. In all the 
countries in the sample, this variable by far showed the highest degree of accuracy in predicting bank problems. Moreover, the quality of the indicator was superior as demonstrated by the very high ratio of "good" to "bad" signals, that in some countries surpassed a ratio of 2.5. ${ }^{28}$

To improve the signals about bank risk emanating from deposit markets, policymakers should encourage the public offering of uninsured certificates of deposit. This would allow investors to compare rates offered by various banks. Moreover, banks need to publish their prime interest rates (those offered to the best clients) to set a benchmark for pricing credit risk. Publishing interbank bid and offer rates would also improve the flow of information on bank quality.

\section{b. Concentrate Regulatory Efforts on the Improvement of Domestic Financial Safety Nets}

Market discipline cannot work if deposit insurance is badly designed, central banks procedures do not restrict bank access to liquidity, and prompt corrective actions to deal with problem banks are not in place.

Bankers who feel that their depositors will not stage a run because of the expectations of unrestricted deposit insurance will have an incentive to increase the risk of their portfolios. Depositors, in turn, will not have the incentive to monitor banks' performance. Properly designed deposit insurance would credibly limit the coverage to small depositors to further encourage the more efficient pricing of risk in large deposit markets.

Credibility of deposit insurance also requires that the other institutions forming part of the financial safety net, the central bank as a lender of last resort and the banking supervisory authority, combine efforts to reduce the moral hazard problem intrinsic in deposit insurance schemes. Central banks' operating procedures need to strictly limit bank access for funding. Bank liability holders that perceive an unrestricted access of banks to central bank funds will not have an incentive to exert market discipline. Operational procedures of the central bank should require that banks' shortages of cash be met in the interbank market.

A limited deposit insurance system will also not be credible if "prompt corrective actions" to deal with banking problems are not in the toolbox of the supervisory authority. If problems are allowed to mount without the legal mechanisms to control the expansion of risk, depositors will perceive "bail out" as the only alternative left for supervisors.

28. Remember that a ratio of 1 indicates that the indicator provided "good" signals 50 percent of the times. 


\section{c. Encourage the Process of Financial Internationalization}

While the above recommendations aim at dealing with the problem of ineffective capital requirements, the long-term objective of achieving at least the same level of effectiveness that capital requirements have in the most advanced emerging countries should not be lost from sight. Consolidated supervision as well as rules and regulations for improving the liquidity and depth of capital markets, while necessary, will not be sufficient. Market depth can only be achieved if a diverse group of investors and users of capital enter the market; that is, if the market becomes less concentrated. To this end, further encouraging the internationalization of emerging market banking systems is the way to go because, in general, foreign banks would reduce the interrelationship between financial and real wealth in the domestic economy.

In this regard consider the recent experience in the seven largest emerging markets in Latin America (not necessarily the most financially developed.) ${ }^{29}$ Table 3 shows that by end2000, foreign participation in total equity in Chile reached 53 percent. Chile, the country in Latin America with the highest "financial depth" as measured by the ratio of broad money to GDP, is also the country with the highest participation of foreign banks. Chart 4 shows that this has been an ongoing process that has extended over a number of years. The chart shows the evolution of "Effective Control of Foreign Banks in Latin America" as defined by Salomon Smith Barney, namely, the ratio of loans provided by foreign banks that have a stake of at least 40 percent in the local institution to total loans in the banking system. It clearly shows that, albeit at different pace, all the countries have significantly internationalized their domestic banking systems since the second half of the 1990s. Mexico stands out by its sharp determination to carry this process further. The data in chart 5 does not include the recent sale of BANAMEX, one of the two largest Mexican banks, to Citibank.

29. For example, by practically all standards, Panama has a more financially developed system than Venezuela. 
Effective Control of Foreign Banks in Latin American Banking Systems; 1996-2000

(Foreign Effective Control of Total Loans)

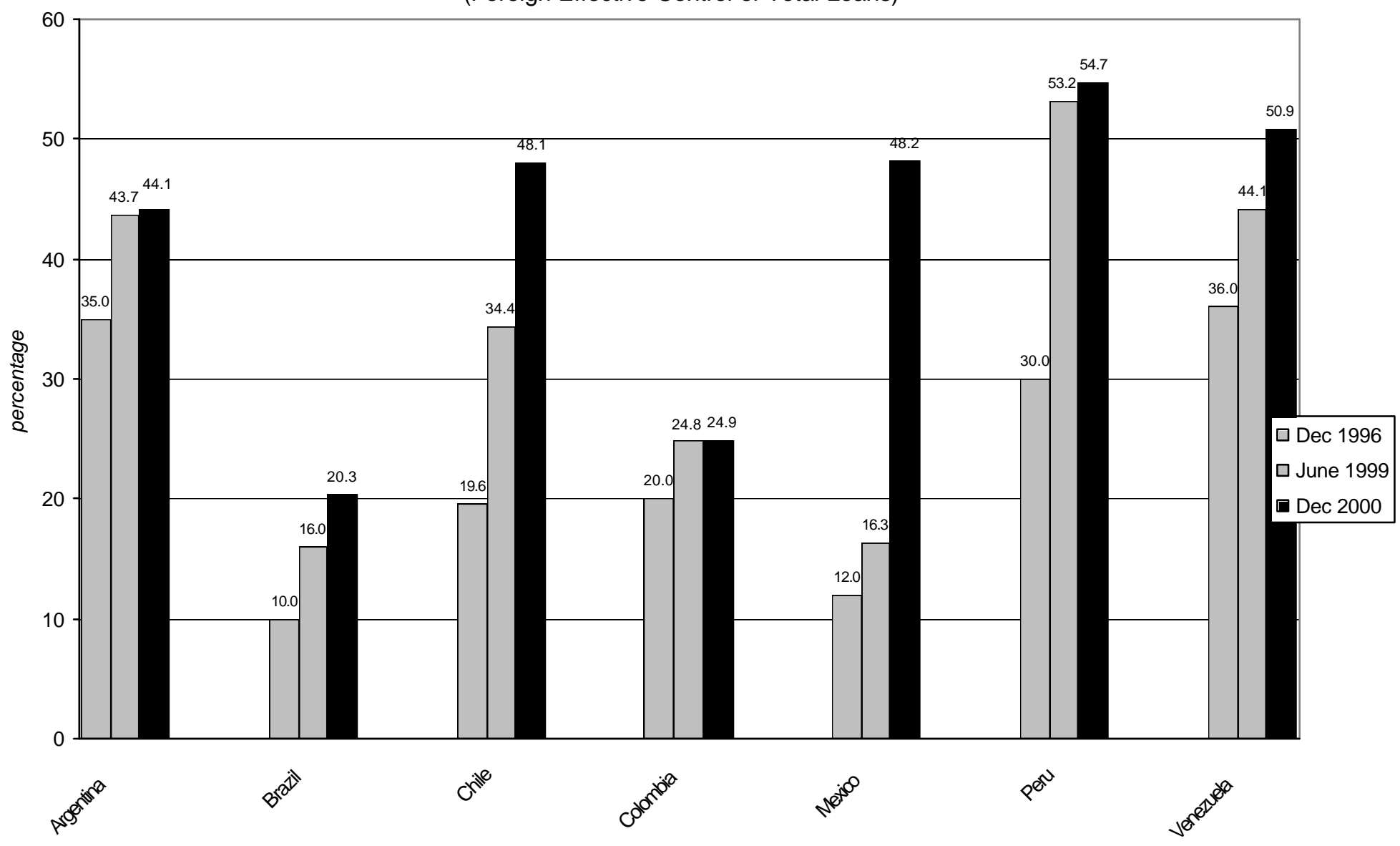

It is important to note that an argument of those against the internationalization of banking has traditionally been that foreign banks might focus on providing funds for large corporations with no particular interest in funding small businesses and consumers. That is, the concern is that foreign banks would concentrate on "wholesale banking" as opposed to "retail" banking. The recent experience in Latin America can be useful to test that hypothesis.

Typically, banks are classified as "mostly wholesale" versus "mostly retail" based on the ratio of demand deposits to total deposits. The argument is that wholesale-oriented banks will have a larger share of demand deposits relative to retail-oriented banks since medium and large-sized corporations need large holdings of demand deposits to meet wages and other working capital payments. ${ }^{30}$ The question that concerns us is whether

30. In general, large corporations do not choose to hold their wealth in the form of savings or time deposits, preferring instead, holdings of real assets and securities. In contrast, consumers and small 
foreign banks behave differently than domestic banks with respect to the ratio of demand to total deposits.

Table 4 presents the average ratio of demand deposits to total deposits for domestic and foreign banks in three Latin American countries with a large participation of foreign banks: Mexico, Peru, and Chile.

Table 4

Average Ratio of Demand Deposits to Total Deposits

\begin{tabular}{|l|c|c|}
\hline & Foreign Banks & Domestic Banks \\
\hline Mexico (as of Sep.2001) & 20.99 & 25.85 \\
\hline Peru (as of May 2001) & 12.39 & 13.4 \\
\hline Chile (as of June 2001) & 33.67 & 27.73 \\
\hline
\end{tabular}

Source: Web sites of the corresponding Banking Supervisory Agency.

Table 4 shows that there are no sharp differences in the average behavior of foreign banks and domestic banks. ${ }^{31}$ Marginally, in Mexico and Peru, foreign banks tend to be more "retailoriented" than domestic banks as the ratio in the former group of banks is lower than the ratio in the latter group. This result may help to ease concerns among policymakers fearing a potentially adverse effect of an increased participation of foreign banks on the availability of funding to small businesses and consumers.

businesses in emerging markets tend to hold a significant part of their savings in time deposits. Notice that large corporations can easily diversify their asset holding in the international capital markets.

31. This result should be taken, of course, as a first approximation only. To be sure that the average ratios is significantly different between the two sets of banks, it would be necessary to conduct a t-test for the difference in the means. 


\section{Policy Recommendations for Countries Where Capital Requirements Are Effectively Enforced}

In the case of emerging market economies where there is sufficient competition in the banking system (mostly because of a large presence of foreign banks) to ensure that banks have an incentive to maintain adequate capital, the issue is the choice of the capital standard. In making their choice, these countries need to take into account that their financial systems still lack welldeveloped and liquid capital markets. The recommendations for this group of countries can be summarized as follows: (a) design a standard that appropriately reflects the risk of banks' assets; clearly Basel (I or II) does not fit the bill; (b) further enhance the mechanisms of market discipline by identifying markets that "work"; and (c) deepen the process of financial internationalization through the increased participation of foreign institutional investors. Needless to say, the discussion in this section presumes that the recommendations advanced for less financially developed countries are met.

\section{a. Set Capital Standards that Reflect the Particular Risks-Characteristics of Assets in Emerging Markets and Initiate Risk-Based Regulations on Loan-Loss Provisions}

Based on the discussion in section III, it is clear that a straight application of the Basel capital standards to emerging markets is not the appropriate way to strengthen banking systems. I need to emphasize here that the problem does not lie in the Accord itself. After all, the Accord was designed as a set of recommendations for the adequate holdings of capital by large banks operating internationally. The problem lies in its application to countries that do not meet the requirements for the Basel standards to work effectively.

This paper has argued that market-based indicators are essential to identify signs of bank weaknesses. However, I have also argued that reliable signals may not be obtained from credit rating agencies or from the internal risk-assessment models of individual banks. Pervasive incentives render both approaches ineffective when applied to banking systems in emerging markets (see section II). ${ }^{32}$ In other words, market discipline works if it is based on markets that have the incentive to "complement" the role of the supervisors.

32. Just to recall, two key problems are: (a) credit rating agencies have the incentive to "inflate" the ratings to obtain the bu sinesses of corporations; and (b) banks allowed to use their own internal risk-assessments models subject to evaluation and acceptance by the supervisory authorities have an incentive to "game the rules" as supervisors in emerging markets do not have sufficient expertise to assess the quality of individual bank's models. This latter problem, however, is also present in industrial countries (see US Shadow Financial Regulatory Committee 2001). 
While there is little that emerging markets can do with respect to the imple mentation of the revised Accord in industrial country banking systems, individual countries need to build buffers against the potentially enhanced volatility of capital flows that the new regulatory procedures could engender. Adequate capital standards can go a long way in achieving this objective. While designing the specific features of such a standard goes beyond the scope of this paper, I have two sets of recommendations.

\section{1) Initiate Risk-Based Regulations in Loan Loss Provisions.}

In a recent paper by Cavallo and Majnoni (2001), it is argued that the role of bank loan loss provisions on the effectiveness of capital requirements has been severely overlooked in emerging markets. I fully agree with this observation. As correctly stated by Cavallo and Majnoni, minimum capital requirements are given a task well beyond their intended purpose. Capital requirements should provide a buffer against unexpected losses, while loan-loss reserves should take care of expected losses. In reality, however, under-provisioning leads to inadequate loan-loss reserves. This inadequacy materializes when an adverse shock hits the banking system. As a result, the gap between minimum required capital and actual capital is larger than if banks had appropriate loan-loss reserves. Therefore, an adequate design of capital standards needs to incorporate an adequate design of loan-loss reserves. I now turn to that issue.

In a separate paper, Rojas-Suarez (1999), I argued that, based on the observed high frequency of banking crisis events in emerging economies, a significant proportion of bank losses can indeed be anticipated. To illustrate my point I will provide an example by focusing on the socalled problem of "liability dollarization." This problem, which was first identified in Latin America, but then included several other emerging market economies, resulted from the process of substitution out of domestic-denominated deposits into dollar-denominated deposits that followed periods of high or hyper-inflation. Because domestic regulations attempt to minimize the currency mismatch in banks' balance sheets, banks provide a significant proportion of their loans in dollars. A problem for the stability of the banking sector arises when, following a significant depreciation of the exchange rate, a sudden currency mismatch between bank loans (dollars) and borrowers' sources of revenues (domestic currency) occurs.

Facing this problem, macro analysts have taken two extremes: some argue for full official dollarization of the economy since no currency mismatch can occur if all transactions (real and financial) take place using the dollar. Some others, however, argue for exactly the opposite prescription: de-dollarize the economy to avoid the problem. I think that neither of these extreme 
proposals is necessary and that they are missing the essence of the problem: the lack of adequate provisioning when extending loans to the nontradable sector.

Let me explain. The problem of liability dollarization presumes that a sharp depreciation of the real exchange rate brings about a reduction in the capacity of the nontradable sector to service their loans. I believe that this is correct and that the evidence substantiates this claim. The evidence also reveals that sharp depreciations of the exchange rate are a recurrent feature in many markets. Taken together, these two sets of evidence seem to imply that, ceteris paribus, expected losses from loans to the non-tradable sector would tend be larger than those resulting from loans to the tradable sector. Exchange rate risk transforms into credit risk for the nontradable sector. Why, then, do banks in emerging markets not have distinct provisioning requirements for these two kinds of loans? The main reason is that emerging market countries do not have cle ar regulations about provisioning, and certainly no risk-based regulations.

The example that I just described needs to be taken simply as an illustration of the severity of the problem associated with inadequate loan loss reserves in emerging markets. A proper analysis needs to estimate probabilities of default for different categories of loans in different countries. By providing information about expected losses, the mean of the frequency distribution of loan losses for separate classes of loans should guide the appropriate design of provisioning requirements. Indeed, empirical analysis on these frequency distributions is the next step in this research agenda. The key message, however, is that, as argued by Cavallo and Majnoni, no capital standard can function properly without appropriate provisioning rules that reflect the risks specific to emerging markets. The example of liability dollarization exemplifies one source of risk particular to emerging markets.

\section{2) Maintain a Simple Classification of Assets According to Risk but Drastically Modify the Risk Categories}

Assuming that loan-loss reserves are designed to reflect the expected losses in banks' assets, minimum capital requirements need to reflect unexpected losses. For the reasons extensively discussed above, I think that a simple capital to risk-weighted assets ratio is appropriate for emerging markets. However, there needs to be two fundamental differences relative to the current Basel Accord. The first, already widely recognized by many authorities in emerging markets relates to the minimum capital requirement. The second is that the categories for classifying credits needs to reflect the risks particular to emerging markets that are, to a large extent, quite different from those in industrial countries. 
I do not have much to add to the already well-accepted recommendation that minimum capital requirements need to be above 8 percent in emerging markets. As noted by Gavin and Hausmann (1996), the higher level of economic and financial volatility in emerging markets relative to industrial countries implies that the buffer stock needed by banks to weather unexpected shocks without becoming insolvent is larger in the former set of countries than in the latter. Going back to our discussion on the frequency distribution of loan losses, higher volatility translates into greater standard deviation for a portfolio's unexpected losses and, therefore, to the need for a larger buffer.

With respect to my second point, namely, the need to identify categories of risks particular to emerging markets, further research is needed to construct such categories. However, the discussion in this paper allows me to advance at least two preliminary conclusions. First, there is the issue of risk weights attached to government paper. Unless governments agree to attach weights to their liabilities that reflect their true (or at least closer to the true) market risk for the purpose of banks' capital charges, banks will discriminate against credit to the private sector relative to the public sector. This regulation-induced "crowding-out" problem harms both the efficiency and stability of domestic financial sectors. Second, in contrast to industrial countries, market risks — especially exchange rate risk—can quickly turn into "credit risk" for some productive sectors, such as the nontradable sector, following an adverse shock. Risk categories for classifying credits need to take this feature into account.

\section{a. Further Enhance the Mechanisms of Market Discipline}

When describing this group of emerging markets, I clarified that, in spite of their efforts, capital markets remain shallow. This constraint limits the use of market discipline to supplement the role of capital requirements.

Lacking liquid equity markets, some emerging market countries have considered requiring banks to issue subordinated debt as a way to enhance market discipline. Argentina can be singled out among emerging markets for already having included a "subordinated debt requirement" as part of its regulatory framework. While the concept is very much in line with my views on market discipline, I have serious doubts that this mechanism could work in the short run in emerging markets. The reason is that in most of these countries the domestic bond market suffers from the same limitations of illiquid capital markets discussed above. Moreover, as recent experience shows, foreign demand for emerging-markets private-sector debt remains extremely volatile. However, to the extent that the authorities are able to develop private bond markets, yields on uninsured subordinated debt can become a market indicator of bank strength, and 
therefore, a complement to capital requirements. According to experts on the Argentinean system, application of the subordinated debt requirement has had some success in enhancing market discipline, but results have so far fallen below expectations. ${ }^{33}$

Another interesting idea that, together with uninsured CDs, enhances information to investors about the quality of banks' assets is the development of credit bureaus in a number of emerging countries, especially in Latin America. Powell (2001) suggests that information from the bureaus could be used to estimate the probability distribution of loan losses and, therefore, to calculate adequate requirements for capital and provisioning.

\section{c. Deepening the Process of Financial Internationalization}

Encouraging foreign firms to manage private pension funds - a business expanding rapidly in emerging markets-could also help to enhance effectiveness of capital requirements. Because of the current underdevelopment of domestic equity and bond markets, pension fund managers will invest a significant part of their funds in bank deposits. Foreign pension funds will choose banks to invest in based on criteria of return and safety, not to build business relationships. This enhanced market discipline would give appropriate incentives for domestic banks to keep capital according to the true riskiness of their portfolios.

\section{CONCLUDING REMARKS}

This paper has dealt with the appropriate design of capital adequacy requirements in emerging markets. It has argued that countries can be divided into two groups according to their capacity to enforce regulatory capital. The first group consists of those economies characterized by: (a) inappropriate accounting standards and reporting systems, improper classification of nonperforming loans and deficient legal and judicial frameworks, unable to enforce supervisory actions; and (b) high concentration of asset ownership, both financial and real, that renders the potential equity market small and uncompetitive. It is shown that under these conditions, capital ratios cannot perform their supervisory role of containing excessive risk-taking activities by banks. It is argued that in such an environment, the intent of the capital standard-to increase the proportion of uninsured funding (equity) to insured (funding) in order to reduce bank stockholders' incentive to take risks at the expense of existing public safety nets-can be easily subverted. This is because supervisors have difficulty in determining whether shareholders' wealth is really at risk when they supply equity capital since shareholders can finance their stake

33. See Calomiris, C. and A. Powell (2001). 
with a loan from a related party, which may even be a nonfinancial corporation, and hence outside the regulators' purview. As there are no capital markets available to validate the "real" value of capital as distinct from its accounting value, capital standards simply do not work.

In the second group of countries, a continuous increase in the participation of foreign banks from industrial countries is de facto reducing the degree of related lending activities among financial institutions and between financial institutions and the real sector. Although there is still no emerging market with sufficiently deep and liquid capital markets, the participation of foreign banks can provide an outside source of capital. The competition induced by the entry of new providers of wealth can indeed contribute to improve the usefulness of capitalization ratios. Furthermore, in this group of countries, the accounting, regulatory, and supervisory frameworks have improved drastically. The relevant question, therefore, is: What is the appropriate capital standard?

Clearly, policy recommendations need to differ significantly between these two groups of countries. For the first group, it is obvious that the sustainable policy consists in removing the constraints to the effectiveness of capital standards; however, those policy reforms often take a significant amount of time. In the transition to a more comprehensive reform, it is essential to identify and develop indicators of banking problems (other than capital ratios) that reveal the true riskiness of banks. Deposit markets have been identif ied as markets that work in most emerging economies in the sense that they have been able to provide effective early warning signals about the relative strength of banks. Recommendations for policymakers, therefore, focus on strengthening the role of market discipline to substitute for the inadequacies of the regulatory capital requirements. Specific recommendations include: (a) encouraging the public offering of uninsured certificates of deposits; (b) publishing interbank bid and offer rates to improve the flow of information on bank quality; (c) concentrating regulatory efforts on the improvement of deposit insurance schemes to further enhance the role of market discipline; (d) restricting bank access to central bank liquidity; (e) improving the credibility of safety nets by establishing "prompt corrective actions" to deal with banking problems; and (f) encouraging the process of financial internationalization as market depth can only be achieved if a diverse group of investors and users of capital enter the market; that is, if the market becomes less concentrated.

To design recommendations for the second group of countries, the paper first explored whether fully adopting the Basel standards (in its current or proposed modified form) was appropriate. The analysis led us to conclude that the implementation of the Accord in emerging markets has created incentives that weakened, rather than strengthened, the franchise value of banks. An example is the preferential treatment of government paper (in terms of capital charges) 
that discourages lending to the private sector, especially during economic downturns.

Implementation of the proposed Basel II would introduce further distortions in the allocation of bank credit.

The main recommendation for this group of countries is to design a capital standard that appropriately reflects the risk of banks' assets; clearly Basel (I or II) does not fit the bill. The standard should have two basic components. The first is the development of risk-based regulations in loan-loss provisions (this is an essential complement to any capital standard). The second is the establishment of a reduced number of risk categories to classify assets, with the central qualification that the categories of risk should reflect the particular features of banks' assets in emerging markets. Issues that need to be considered in the design of appropriate risk categories include an adequate risk assessment of government paper and the introduction of distinct capital charges for borrowers in the tradable and nontradable sectors. Additional recommendations to enhance the effectiveness of the capital standard include: (a) further enhancing the mechanisms of market discipline; and (b) deepening the process of financial internationalization through the increased participation of foreign institutional investors. Needless to say, that all these recommendations presume that those advanced for less financially developed countries (group 1) are met.

In a nutshell, the answer to the question posed in this paper- "can international capital standards strengthen banks in emerging markets"?-is an emphatic no! While the standards are of little relevance for the first group of countries, they do not appropriately reflect the risks of banks' assets in the second group of emerging market countries. 


\section{APPENDIX \\ A SUMMARY OF THE KEY FEATURES OF THE NEWLY \\ PROPOSED ACCORD}

In January 2001, the Basel Committee issued a new proposal to modify the current Capital Adequacy Accord. This new proposal incorporates comments to the first draft issued in June 1999. After a heated debate on the proposal, the Committee decided to postpone the issuance of the final version to 2002. The basic features of the proposal, especially those most relevant to emerging markets, are briefly summarized in this section. ${ }^{34}$

The newly proposed Accord comprises three pillars: (1) minimum capital requirements, (2) supervisory review process, and (3) market discipline. It is the view of the Committee that efficient supervision and effective market discipline are complements to the minimum capital requirements.

Pillar 1: The pillar on minimum capital requirements proposes a menu of approaches to measure credit risk, market risk, and operational risk. The proposed formula to measure capital ratio is:

Bank's capital ratio = Total capital / (Credit Risk + Market Risk + Operational Risk $)$

The new proposed framework leaves unchanged both the current definition of capital and the minimum requirement of 8 percent capital-to-risk-weighted assets. Also, the market risk measure remains the same as in the old Accord. The central objective of Pillar I is to introduce greater risk sensitivity in the design of capital adequacy ratios and, therefore, more flexibility in the computation of banks' individual risks. Toward this end, the proposal: (a) introduces a capital charge for operational risk, and (b) allows for two alternative ways to measure credit risk.

With respect to operational risk (for example, the risk of loss from computer failures, poor documentation or fraud), the Accord proposes three alternative methods for measuring it and it is expected that capital to cover for operational risk would account for about 20 percent of the overall capital requirements.

The most controversial innovation in the proposed Accord rela tes to the measurement of credit risk, which can now follow two approaches. The first, the standardized approach, is a modification of the current practice. In a nutshell, this modified approach has more buckets for classifying credits and is more risk-sensitive. Currently, there are only three categories of risk weights to assign assets, and these categories depend on the broad category of a borrower: 0 percent for government paper of OECD countries; 20 percent for all interbank lending of OECD 
countries and short-term lending to banks in non-OECD countries; and 100 percent for all corporate lending (OECD and non-OECD) and all other loans to non-OECD countries (except short-term loans to banks). The risk weights are to be refined by reference to a rating provided by an external assessment institution, such as a credit rating agency. For example, while in the old Accord there was only one category for corporate lending (100 percent), now there are four categories (20 percent, 50 percent, 100 percent, and 150 percent).

In the second approach, the internal rating-based approach, banks can use their internal estimates of borrower creditworthiness to assess credit risk. There are two levels: (a) the foundation method, where banks estimate the probability of default for each borrower and the supervisors supply other inputs necessary for the estimation of capital charges; and (b) the advanced methodology, where banks with sufficiently developed internal capital allocation processes can supply other inputs as well. In either the foundation or advanced methods, the range of risk weights will be more diversified than that in the standardized approach.

Pillar 2: This pillar proposes a supervisory review process that guarantees the soundness of banks' internal processes of risk evaluation. Supervisors will have responsibility for assessing the appropriateness of banks capital charges relative to their risks. When appropriate, the internal process would be subject to supervisory review and intervention.

Pillar 3: In this pillar, the proposed Accord introduces disclosure requirements as a way to enhance market discipline. A core set of disclosure recommendations will apply to all banks. This includes disclosure about the way a bank calculates its capital adequacy and its risk assessment methods.

34. For a more detailed summary, see BIS (2001). 


\section{REFERENCES}

Bank for International Settlements. 2001. The New Basel Accord: An Explanatory Note.

Secretariat of the Basel Committee on Banking Supervision.

Benink, Harald and Clas Wihlborg. 2001. The New Basel Capital Accord: the Risk of an Unlevel Playing Field. Erasmus University Working Paper.

Calomiris, Charles and Andrew Powell. 2000. Can Emerging Market Bank Regulators Establish Credible Discipline? The Case of Argentina, 1992-99. Central Bank of Argentina Working Paper no. 14, May.

Cavallo, Michele and Giovanni Majnoni. 2001. Do Banks Provision for Bad Loans in Good Times? Empirical Evidence and Policy Implications. World Bank, June.

Ferri, Giovanni, Ligang Liu, and Giovanni Majnoni. 2000. How the Proposed Basel Guidelines on Rating-Agency Assessments would Affect Developing Countries?

World Bank Working Paper.

Griffith-Jones, Stephanie and S. Spratt. 2001. Will the Proposed New Basel Capital Accord Have a Net Negative Effect on Developing Countries? Photocopy, Institute of Development Studies, University of Sussex.

Gavin, Michael and R. Hausmann. 1997. Make or Buy? Approaches to Financial Market Integration, in Rojas-Suarez, L. (ed), Safe and Sound Financial Systems: What Works for Latin America, IADB, Washington, DC.

Gavin, Michael and R. Hausmann. 1996. The Roots of Banking Crises: The Macroeconomic Context, in Hausmann, R. and Rojas-Suarez. L. (eds.), Banking Crises in Latin America, IADB, Washington, DC.

Latin American Shadow Financial Regulatory Committee. 2001. The New Basel Capital Accord and Financial Stability in Latin America. Statement no. 2, April. http://www.aei.org.

Powell, Andrew. 2001. A Capital Accord for Emerging Economies? Photocopy, Universidad Torcuato Di Tella, September.

Reinhart, Carmen. 2001. Sovereign Credit Ratings Before and After Financial Crises, World Bank Economic Review (forthcoming).

Reisen, Helmut. 2001. Will Basel II Contribute to Convergence in International Capital Flows? Photocopy, OECD Development Centre, May.

Rojas-Suarez, Liliana. 2001. Rating Banks in Emerging Markets: What Credit Rating Agencies Should Learn From Financial Indicators. Institute for International Economics Working Paper WP01-6, May.

Rojas-Suarez, Liliana. 2001a. What Exchange Arrangement Works Best for Latin America? In Willett, T. (eds), forthcoming. 
Rojas-Suarez, Liliana and Steven Weisbrod. 1997. Toward an Effective Financial Regulatory and Supervisory Framework in Latin America: Dealing with the Transition. In Rojas-Suarez, L. (ed), Safe and Sound Financial Systems - What Works for Latin America, IADB, Washington, DC.

Rojas-Suarez, Liliana. 1999. Dollarization in Latin America. Testimony before the US Senate, July.

Rojas-Suarez, Liliana and Steven Weisbrod. 1995. Financial Fragilities in Latin America: The 1980s and 1990s. IMF Occasional Paper no. 132, Washington, DC, October.

Salomon Smith Barney. Foreign Financial Institutions in Latin America, various issues.

Shadow Financial Regulatory Committees of Europe, Japan, Latin America, and the United States. 2001. Joint Statement by a sub-group of the Committees, Reforming Bank Capital Regulation, Amsterdam, June 18. http://www.aei.org.

US Shadow Financial Regulatory Committee. 2001. Statement no. 169, February. http://www.aei.org. 